\title{
Classroom practices and consequent transformation in beliefs towards Science Teaching: A case study of Elementary School Science Teacher
}

\author{
Nasir MAHMOOD*
}

\begin{abstract}
The study aimed at making evident the process of change in the beliefs of a science teacher resulting from classroom practices. The process of change was addressed by finding the beliefs held in comparison to other teachers, compatibility of held beliefs with constructivist principles of learning and changes observed during the two years. The data were collected through science teacher belief questionnaire, video recordings and teacher interview. Some encouraging evidence was in favor of practice changing beliefs about student involvement in lessons were found. The teacher started valuing students' agreement on outcomes of the learning and spent more time in listening to the students rather than instructing them. The sequence in which changes were observed has great potential for facilitating the Continuous Professional Development (CPD) of teachers.
\end{abstract}

Keywords: Science teaching, continuous professional development, change in beliefs, constructivism.

* Assoc. Prof. Dr., University of the Punjab, Institute of Education and Research, Department of Research \& Evaluation, Lahore, Pakistan. E-mail: mahsir1@yahoo.com 


\section{INTRODUCTION}

Teachers' beliefs are one of the most extensively investigated subjects in educational research. The reason is very obvious, for a teacher is very likely to practice whatever he/she assumes about and the way content is best learned by the students. Researchers have seen the study of teacher beliefs as an opportunity to understand - classroom practices. Teachers' beliefs about the nature of scientific knowledge, objectives of teaching, nature of learning, students' role in learning, supportive classroom environment, and role of teacher, have been the most studied fields in the area of beliefs (Chan \& Elliott, 2000; Davis, Konopak \& Readence, 1993: Fang, 1996; Fulton \& Torney-Putra, 2000; Pajares, 1992). There is ample evidence to indicate that teachers' beliefs influence their classroom practices (Brickhouse, 1990; Bryan \& Atwater, 2002; Levitt, 2002; Munby, 1982; Pajares, 1992; Prawat, 1990, 1992; Richardson, 1996; Waters-Adams, 2006) but research on how far practice in the classroom changes a teacher's beliefs is tentative (Abd-ElKhalick, Bell \& Lederman, 1998; Brickhouse, 1990; Lederman, 1999; Lederman, Gess-Newsome \& Latz, 1994; Levin \& Wadmany, 2005). What researchers are convinced is that the interactive relationship of beliefs and practices influence each other in a cyclic fashion (Verjovsky \& Waldegg, 2005).

Before undertaking a review of the current status of research on science teachers' beliefs it seems appropriate to define the term beliefs as used in this research to avoid any confusion as the term has been traditionally used to describe a variety of constructs by different researchers (Pajares, 1992). In the context of this research, it is assumed that beliefs are inferred from a situation being experienced by an individual. It is also assumed that beliefs are context dependent (Cooney, Shealey \& Arvold, 1998) and held to different degrees by different individuals.

\section{Developments in research on teacher's belief}

Teacher beliefs are recognized as difficult constructs to explore and change (Pintrich, 1990) but if explored successfully, they can provide very useful psychological insights for the improvement of teaching and learning. Kagan (1992) summarized more than twenty-five qualitative and quantitative research studies carried out in the last two decades for exploring practicing and prospective teachers' beliefs. Ideas such as self-efficacy, convictions about teaching methodology, student behaviors, classroom discipline, process of learning and the teacher's role in the classroom have all been explored in detail. Overall findings showed that a relationship 
existed between teacher beliefs and the quality and extent of learning and achievement of students.

One domain not included in Kagan's (1992) analysis was the relationship of teacher's epistemological beliefs about science as a body of knowledge and implications for school teaching. The studies explicitly addressing this rather philosophical issue are very few (Tsai, 2002; p.772) but researchers have shown that epistemological beliefs play a key role in the way that teachers interpret scientific knowledge and in turn teach it in classroom (Pajares, 1992; p. 325, Gallagher, 1991; p.132, Hashweh, 1996; p.61).

The present work reports a retrospective case study of a science teacher (Fujita) in which the relationship of his practices to beliefs is studied in an attempt to determine the shift in his beliefs resulting from continued use of practices found in constructivist literature regarding nature of scientific knowledge, extent of student participation in learning and teaching and learning of science over a period of two years. In the first year of the study the researcher worked very closely with the teacher in order to develop mutual understanding about the practicability of very obvious looking constructivist principles. A collaborative effort was then made to use the selected constructivist principles for almost one academic year in the science classroom of grade five.

\section{Constructivist principles selected for implementation in classroom}

Science teachers find constructivist explanations of learning quite appealing (Brooks \& Brooks, 1999) as these resonate with how learning and teaching in science is normally conceived. As a result a change in beliefs may be initiated relatively readily but translation of the principles for classroom practice can prove problematic (Appleton \& Asoko, 1996). There is hardly any concrete guidance about the instructional strategies helpful in becoming a constructivist teacher (Nasir, Kono \& Fujita; 2002) thus requiring teachers to use the same teaching methods as they were already using but aiming to achieve a different kind of learning. The researcher and Fujita realized the potential difficulties facing us when implementing these constructivist principles but the most encouraging factor was the flexibility offered to the teacher in the Japanese elementary school system. The elementary school classrooms are comparatively student-centered in which students actively participate in class activities unlike junior high and high schools where focus is preparation for very highly structured public examination. Teacher is reasonably independent in selection of instructional material, class activities and students' assessment. There are multiple textbooks produced by various publishers and teacher/school can select any 
from them. Similarly, there is no public examination till the end of grade VI and teacher is solely responsible to write student assessment report. The condition described empower teacher to relatively autonomously decide the order, duration, class activities and modes of assessment.

Keeping in view the practicability of selected principles in provided school and class atmosphere we mutually agreed to put the following constructivist principles into practice;

1. providing greater opportunity to students to talk their mind,

2. valuing students' opinion,

3. helping students' to make sense of class talk,

4. developing consensus among class fellows on the learned, and

5. appreciating new scientific ways of describing phenomena.

Lesson planning was carried out on a lesson-by-lesson basis through reflecting on the pros and cons of the immediate previous lesson and planning for the next lesson in the light of experience and how requirements evolved. Researcher was involved in the planning process but the teaching was done by Fujita alone. The researcher was always present in the class doing the video recording and observing for our after class reflective analysis.

\section{Background of the Study}

The partnership with Fujita started by the researcher attending the science class taught by him to know about the science teaching in Japanese elementary schools, making acquaintance with the students in that class to minimize the potential impact of the observer on the behavior of students and having combined study sessions to develop a common understanding of theoretical underpinnings of constructivist principles of learning with the teacher. It was during this period of combined reading that the teacher developed his interest in the constructivist explanation of the learning process and decided to try them in the classroom to determine their viability for classroom teaching and learning.

It is important to note that Fujita's views on nature of scientific knowledge, students participation in lesson and teaching of science were recorded incidentally when the Science Teacher Belief Questionnaire (STBQ) was administered to a group of science teachers from Tokyo area as part of data collection for doctoral research. We came to know each other later on when I was introduced to him formally for potentially working with him for data collection of my doctoral research on investigating students understanding of science in constructivist classroom. 


\section{Teacher's profile}

Fujita was 45 years of age, at the beginning of this study in 2001 . He graduated in science teaching and is one of the comparatively few specialized science teachers in Japanese elementary schools. He has more than 21 years of experience of teaching science in elementary schools and has worked in this school for almost two decades. This school, being attached to the Tokyo Gakugei University, has a research supportive environment requiring teachers to participate in science teachers' meetings to share their experience and present their work on classroom practice. Fujita has membership of a science education society and was a member of the team which wrote science textbooks widely used in elementary schools. He has publications in science education periodicals. He was also invited occasionally, by the faculty of science in Tokyo Gakugei University, for lecturing to the undergraduates.

\section{Objectives}

The purpose of the study was to make evident the process of change in the beliefs and practice of Fujita when involved in constructivist practice for an extended period of time. Being an experienced teacher, Fujita was asked to reflect on what kind of changes he perceived in his way of teaching and how far these were evident in his practice. The guiding questions were: (a) what beliefs did he hold about science? (b) how similar were his beliefs about nature of science, student participation in lessons and science teaching to fellow science teachers at the beginning and end of the study? (c) to what extent could his beliefs be considered to be constructivist-compatible? (d) what kind of changes occurred in his beliefs during the two years? and (e) did his teaching reflect his change in beliefs?

\section{METHODOLOGY}

This section describes sources of data, data collection procedure and data analysis.

\section{Description of sources of data}

Science Teacher Belief Questionnaire (STBQ): Researcher made questionnaire comprising of 32 questions on a Likert-type scale about the nature of scientific knowledge, effects of technology on teacher, student participation in lessons, nature of student evaluation, and teaching and learning of science was used for finding the beliefs of elementary school science teachers. 
The three domains i.e. nature of scientific knowledge, student participation in lessons and teaching and learning of science in the questionnaire were relevant to this case study. Therefore teachers' response on those three domains (collectively having 20 statements in the questionnaire of 32 questions) will be used in this study. Table 1 describes the constructs included in the three domains from which data will be used in this case study.

Table 1. Description of the constructs inquired in $S T B Q$

\begin{tabular}{|c|c|c|c|}
\hline Belief domain & Constructs inquired & Example from STBQ & $\alpha$ \\
\hline $\begin{array}{l}\text { Nature of scientific } \\
\text { knowledge } \\
\text { (4 items) }\end{array}$ & $\begin{array}{l}\text { - Process of generation of scientific } \\
\text { knowledge, } \\
\text { - Nature of science as a body of } \\
\text { knowledge, } \\
\text { - Social and cultural context of } \\
\text { science, and } \\
\text { - Responsibility of developing } \\
\text { scientific knowledge }\end{array}$ & $\begin{array}{l}\text { Exploring new knowledge } \\
\text { is the job of the scientists, } \\
\text { we and students should } \\
\text { only benefit from it by } \\
\text { learning it as delivered to } \\
\text { us (negative statement). }\end{array}$ & 0.72 \\
\hline $\begin{array}{l}\text { Student } \\
\text { participation in } \\
\text { lesson } \\
\text { (4 items) }\end{array}$ & $\begin{array}{l}\text { - Students' role in decision making } \\
\text { of the objectives of learning. } \\
\text { - Student-centered approach in } \\
\text { teaching } \\
\text { - Listening and valuing students' } \\
\text { experiences. } \\
\text { - Participation of Student in } \\
\text { evaluation of learned by getting } \\
\text { their self-evaluation. }\end{array}$ & $\begin{array}{l}\text { Student participation in } \\
\text { lesson means to share their } \\
\text { ideas when deciding the } \\
\text { objectives of the lesson. }\end{array}$ & 0.52 \\
\hline $\begin{array}{l}\text { Teaching science } \\
\text { (12 items) }\end{array}$ & $\begin{array}{l}\text { - Intent of teaching and learning } \\
\text { - Teacher's role in the classroom } \\
\text { - Place of previous knowledge and } \\
\text { experience of students in teaching } \\
\text { and learning. } \\
\text { - Selection of methodology } \\
\text { - Contribution of classroom } \\
\text { environment of teaching and } \\
\text { learning. } \\
\text { - Structuring of learning around } \\
\text { concepts } \\
\text { - Relationship of science to other } \\
\text { subjects. }\end{array}$ & $\begin{array}{l}\text { Over simplification of } \\
\text { scientific concepts while } \\
\text { teaching is similar to } \\
\text { giving incomplete } \\
\text { knowledge. }\end{array}$ & 0.50 \\
\hline
\end{tabular}

The constructs in each domain were selected on which constructivists beliefs are distinctly different than non-constructivists and the statements in the questionnaire were specifically focusing the aspects where proximity with constructivist beliefs was distinctly measurable. The examples given in 
the table are meant to demonstrate the language and pattern in which constructs were operationalize.

The validity of the scale was determined through getting the items reviewed by three experts from public sector universities having experience and publications in the field of teacher beliefs.

\section{Interview schedule}

The Interview was a follow up activity of STBQ, focusing on collecting elaborative remarks on the beliefs in which change was noticed over a period of two years. The interview questions which related to three domains relevant to this case study (described in table 2) were used only. The Interview was semi-structured in nature to offer flexibility to the interviewer for asking follow-up questions to collect pertinent information. The interviewer started the interview with the questions in STBQ and by giving a comparison of Fujita's response on it in 2001 and 2003 and then following up with questions which were based on the response of the teacher.

\section{Class observation through video recordings}

Video recording of the teacher was made during the sequenced lessons on the unit about "solution". The recording was focused on the teacher and students involved in whole class talk. This topic was completed in nine lessons of 40 minutes each and all lessons were recorded and transcribed. The lessons were carried out in a science laboratory having six tables with 67 students sitting around each table.

The first two lessons were excluded from the analysis because students were involved in the discussion of non-relevant issue and thus the talk was irrelevant to the concept under study and the unit was restarted from lesson 3. Another video recording session comprising of seven lessons was carried out when the teacher taught the same topic to the same grade (different students) in 2003. The sequence and concepts covered in these recordings is given by year in Table 2 . 
Table 2. Distribution and sequence of lessons by concept and year

\begin{tabular}{lcc}
\hline & \multicolumn{2}{c}{ Grade 5} \\
\cline { 2 - 3 } Content & $2001(\mathrm{dd} / \mathrm{mm} / \mathrm{yy})$ & $2003(\mathrm{dd} / \mathrm{mm} / \mathrm{yy})$ \\
\hline Concept 1: Dissolving salt in 50 ml. of water and & Lesson 3 & Lesson 1 \\
observing the changes & $01 / 11 / 2001$ & $28 / 01 / 2003$ \\
Concept 2: How much salt can be dissolved in 50 & Lesson 4 & Lesson 2 \\
ml. of water? & $06 / 11 / 2001$ & $30 / 01 / 2003$ \\
Concept 3: Observing any change in the volume & Lesson 5 & Lesson 3 \\
and/or weight of solution after dissolving 10gm. of & $08 / 11 / 2001$ & $13 / 02 / 2003$ \\
salt in 50 ml. water. & & \\
Concept 4: Observing the effects of temperature on & Lesson 6 & Lesson 4 \\
the solubility of solution. & $09 / 11 / 2001$ & $20 / 02 / 2003$ \\
Concept 5: Methods of extracting salt from the & Lesson 7 & Lesson 5 \\
solution. & $15 / 11 / 2001$ & $25 / 02 / 2003$ \\
Concept 6: Making solution using other solvents & Lesson 8 & Lesson 6 \\
like boric acid. & $22 / 11 / 2001$ & $27 / 02 / 2003$ \\
Concept 7: Concluding the unit. & Lesson 9 & Lesson 7 \\
& $06 / 12 / 2001$ & $06 / 03 / 2003$ \\
\hline
\end{tabular}

*Lesson $1 \& 2$ on $18 / 10 / 2001$ and $26 / 10 / 2001$ were excluded from the analysis because students were involved in the discussion of non-relevant issue and thus the talk was irrelevant to the concept under study and the unit was restarted from Lesson 3.

\section{Framework used for analyzing video recordings}

The lesson recordings were transcribed and analysis of teacher-student and student-student talk was undertaken for whole class scenarios only. Newton's (2002) categories of class talk were used for classifying class protocol into teacher talk and student talk. Teacher talk was further classified into tuning, connecting, monitoring and direction talk, while student talk was categorized as response, self-initiated and queries.

Tuning Talk includes encouraging students to recollect their mental resources (like experiences, previous learning, etc.), checking sufficiency and quality of those resources, scaffolding where necessary, drawing the aim of the lesson and getting students ready to enter an activity by accepting and valuing their ideas and experiences.

Connecting talk is about helping to establish the link between current learning, already learned concepts and future learning by exploring patterns, relationships, reasons and causes. It involves accepting students' ideas and leading them into extending those ideas by putting immediately verifiable challenges. It is also meant to keep the students focused on the lesson objectives and see the learning activity in context

Monitoring talk is used for judging the student's progress during the lesson. It comprises of the teacher questions about content, process and value judgment of the learned. This provides a formative assessment of the progress of students. 
Directions are not directly related to the concept addressed in the lesson but are pre-requisite for carrying out the learning activity successfully. It deals with class management issues e.g. instruction for using equipment, discipline, setting time limits for various phases of lesson.

Student talk was divided into three categories; responses, self-initiated talk and queries. In student talk, the first category namely response, is mostly initiated by teacher but sometimes can be initiated by the students giving comments or asking questions to other students. Some of the situations can be when the teacher asks questions to check the understanding of on-going learning activities (monitoring), progress in experimental detail, or check on procedural verification. It may also result from sharing results on demand or supporting/criticizing comments from fellow student or the teacher, clarifying one's own statement, accepting the teacher's explanation, or justifying one's own position. The second category includes talk when the student volunteers an idea, observation, experience, opinion or addresses the issue under discussion. It may be in the form of a question setting direction for thought or adding new a dimension to the point under discussion. The provocation may come from the teacher's talk or class fellows but the respondent is not obliged or expected to contribute the shared information. It can also be in the form of an addition to other students' comments or clarification of one's own position. The third category of student talk comprises of queries which include students asking the teacher or fellow students for further clarification of their previous explanation. It may also include questions addressing the teacher's directions, mostly about procedural issues.

Newton's framework allows for linking the teacher and student talk to the constructivist principles selected, to be put into practice for this research. The quantitative changes in student talk, particularly self-initiated talk, indicated change towards opportunities for students to speak their mind in the classroom (principle 1). The change in tuning talk indicated the extent to which the teacher valued students' opinions (principle 2). Making sense of class talk (principle 3) and developing consensus among class-fellows of what was learned (principle 4) was seen through comparing connecting talk in two classroom observations. The analysis of students' responses and monitoring talk by the teacher provided evidence of the teacher appreciating the students' way of describing and understanding scientific phenomenon (principle 5).

The data were analyzed by considering one utterance as a basic unit of count. An utterance was defined as a complete meaningful segment of conversation dealing with a single continuous idea. An utterance can be comprised of one word or one small paragraph depending on the context and demand of the situation.

The rationale for using an utterance as the unit of analysis was a focus on the content of talk rather than the quantity of talk. It was observed during 
a review of the data that sometimes a long sentence does not convey the meaning which a single word can. Thus mere counting of words can mislead the reader about the actual value of classroom discourse.

\section{Data collection procedure}

There were multiple sources of data used to identify and address the various components of the study. The data selected for this case study is a part of information collected through a researcher made STBQ, video recording of lessons on Solution in 2001, interviews about the nature of science, students' participation in lessons and science teaching and video recording of lessons on Solution in 2003 by the same teacher. The time-line and use of the data is described in table 3. The data collection started with the STBQ being distributed to 160 science teachers in a meeting of science teachers in the attached school of Tokyo Gakugei University during a professional development session and collected at the end of the same session. This data helped in comparing Fujita's beliefs about the nature of scientific knowledge, student participation in lesson and teaching \& learning of science to beliefs held by other Japanese science teachers.

Table 3. Time line, instruments and usage of data collected

\begin{tabular}{|c|c|c|c|}
\hline & Type of Instrument & Period & Use of the data collected \\
\hline 1. & $\begin{array}{l}\text { Science Teacher Belief } \\
\text { Questionnaire (STBQ) }\end{array}$ & April 2001 & $\begin{array}{l}\text { Compatibility of Mr. Fujita's beliefs about the } \\
\text { nature of scientific knowledge, student } \\
\text { participation in lesson and teaching \& learning of } \\
\text { science resulting from the practice with other } \\
\text { Japanese teachers. }\end{array}$ \\
\hline 2. & $\begin{array}{l}\text { Video recording of } \\
\text { lessons on Solution }\end{array}$ & $\begin{array}{l}\text { Nov.-Dec. } \\
2001\end{array}$ & \multirow{2}{*}{$\begin{array}{l}\text { To find the changes in the practices of the teacher } \\
\text { over a period of two years. Recording of all lessons } \\
\text { on 'solution' covering various sub-topics. Each of } \\
\text { the recordings was transcribed. }\end{array}$} \\
\hline 3. & $\begin{array}{l}\text { Video recording of } \\
\text { lessons }\end{array}$ & $\begin{array}{c}\text { Jan.- March } \\
2003\end{array}$ & \\
\hline 4. & $\begin{array}{l}\text { Science Teacher Belief } \\
\text { Questionnaire (STBQ) }\end{array}$ & March 2003 & $\begin{array}{l}\text { Find change, if any, in the beliefs of Mr. Fujita about } \\
\text { the nature of scientific knowledge, student } \\
\text { participation in lesson and teaching \& learning of } \\
\text { science resulting from the practice during 2001-03. }\end{array}$ \\
\hline 5. & $\begin{array}{l}\text { Interview about nature } \\
\text { of science, students' } \\
\text { participation in lessons } \\
\text { and science teaching }\end{array}$ & March 2003 & $\begin{array}{l}\text { To seek explanation of the change he reported in } \\
\text { his beliefs regarding the nature of scientific } \\
\text { knowledge, student participation in lesson and } \\
\text { teaching \& learning of science resulting from } \\
\text { practice. The questions by the interviewer were } \\
\text { based on Fajita's answers in the STBQ in March } \\
2003 \text {. }\end{array}$ \\
\hline
\end{tabular}


The next stage of data collection was the video recording of lessons on 'solution' in November 2001 and March 2003. There were 38 and 37 students in the class in 2001 and 2003 respectively. The students were of mixed ability and almost equally distributed by gender. These recordings with a gap of one year in between were used to find out how his practice had responded to the theoretical appeal of the constructivist principles of learning understood as a result of the combined study sessions with the researcher.

At the end of recording these sequenced lessons, the same STBQ was again administered to Fujita to record changes in his responses in comparison to 2001. An interview was also carried out in March 2003 to get detailed information on the nature of change in the beliefs reported by him through STBQ concerning the nature of scientific knowledge, student participation in lessons and the teaching and learning of science.

\section{RESULTS}

\section{Comparison of Fujita's beliefs with other science teachers}

At the beginning of the study Fujita's mean score in all three domains was less than his fellow science teachers who participated in the survey. There were a different number of items in some domains of STBQ, therefore per item mean would be a better measure to understand the size of the difference between Fujita's beliefs and his fellow science teachers for comparison purposes. The difference in the per item score of Fujita and other teachers was calculated by subtracting their respective item mean scores, which was calculated by dividing the mean domain score by the number of items in that particular domain. The mean per item difference between Fujita and other science teachers in the nature of scientific knowledge (NSK), student participation in lesson (SPL) and the teaching and learning of science (TLS) is $0.55,0.18$ and 0.16 respectively. The difference is small enough to assume that Fujita was more or less similar to all other science teachers serving in other elementary schools of Tokyo, apart from his views about the nature of scientific knowledge (NSK). The comparison of mean scores is shown through bar one and two in Fig.1. 


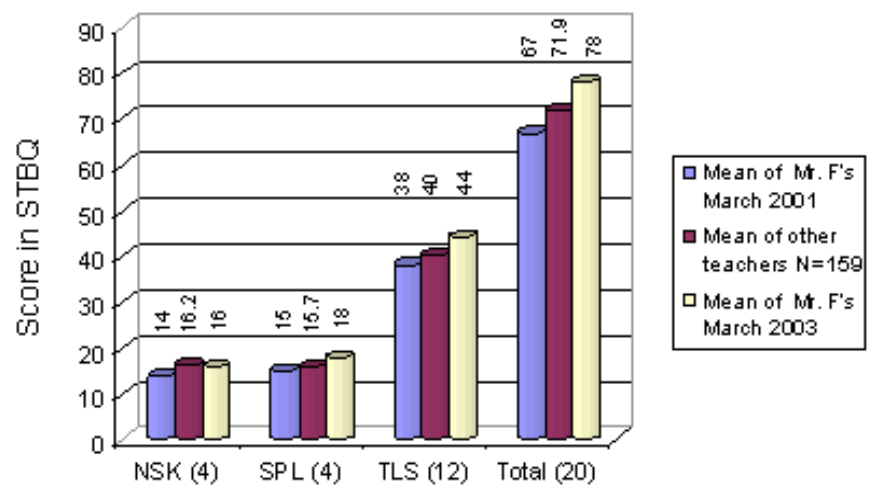

Figure 1: Changes in the teacher's beliefs about science in two years and comparison with mean score of other teachers on three domains of teacher beliefs

NSK $=$ Nature of scientific knowledge SPL $=$ Student participation in lesson TLS $=$ Teaching of science Mr. F = Mr. Fujita () Number of questions

\section{Comparison of changes in Fujita's beliefs over a period of two years}

Figure 1 (bar one and three) provides the comparative change in Fujita's beliefs over a period of two years as a result of practicing selected constructivist principles in his classroom. An increase in all three domains is observed although attributing this change solely to Fujita's classroom practices may be very difficult to claim as none of the other factors, like effect of routine summer continuous professional development program, potentially contributing to this change were controlled. In addition, this change in belief is recorded through STBQ on a Likert-type scale, which is criticized by researchers for its reliability, lack of context potentially undermining the point on which the respondent focused while responding, and insufficiency of good ways for determining how important the issue was to the respondent and whether it brought forward the central belief held by the respondent (Ambrose, Philipp, Chauvot \& Clement, 2003). Despite all these reservations, the change in Fujita's score provides a valid base for exploring areas in which Fujita appeared to change in his beliefs. These areas were later used as a starting point for designing interview questions. The most noticeable change occurred in Fujita's beliefs about the students' participation in the lesson $(0.75 /$ item score i.e. 4.5 mean score per item in 2003 as compared to 3.75 in 2001) followed by nature of scientific knowledge $(0.50$ /item score i.e. 4.0 mean score per item in 2003 as compared to 3.5 in 2001) and the teaching and learning of science (0.49/item score i.e. 3.66 mean score per item in 2003 as compared to 3.17 in 2001). 
It may not be appropriate to attribute this change in score to a change of beliefs definitively but keeping in mind the constructivist principles agreed for practice (between researcher and him) and his beliefs in 2001, it is noticeable that by 2003 the evidence suggests that he seemed to start viewing student participation as a beneficial tool for teaching science. The same became further evident when Fujita was interviewed to elaborate on possible reasons for a change in his score on STBQ.

\section{Interview for exploring the self-reported changes in belief}

When asked about what was the most important transformation he went through as a teacher because of practicing constructivist principles (already agreed between him and researcher) in his teaching during these two years, the most prominent change in his beliefs was about the participation of students in the process of teaching and learning. It can be inferred from his interview that increased student participation in his lessons allowed him to explore students' previous knowledge, building lessons in connection with what students know and to give a sense of ownership of what was learned to the students. At the same time, he was conscious about the potential risk of students working independently and mutually agreeing upon a different scientific explanation than that given in textbook.

A good lesson is one in which students agree on the outcome of the lesson even if the results are not as expected by the teacher (or textbook). If, students could not reach a scientifically accepted answer sometime but realized the mistake they made and have willingness to repeat the activity and correct it, this also indicates a good science lesson having opportunity of students to learn science. (This translation from Japanese language is not word-for-word).

His answer has already shown that he has started valuing student participation a lot more and the same becomes further prominent when asked about how he sees the extent to which students' participation is needed in a lesson. There is clear recognition of student participation at each stage as an important component of class teaching but at the same time he is cautious about the capacity of students to perform this role effectively. But one change which is clear is that he places more importance on involving students in the lesson.

It is ideal to have students participating in all components from lesson plan to end. But to reach a stage to be able make plan, they need a lot of training (study). They need such experience, if not it is hard to participate in good planning. But finally, it is good if they make learning plan, do experiments, record results, and discuss results too (among themselves). (This translation from Japanese language is not word-for-word). 


\section{Context of the teacher's answer}

This answer refers to the class situation where students are already divided in to groups and asked to think of methods to test the conditions of germination given in the book. They are expected to plan the activity, decide procedure, select tools, record data, deduct results and present to class fellows at the end of the lesson.

As far as the role of teacher is concerned he believes that the teacher is to respect what students are doing and facilitate progress only when needed. The best way is to let them explore their own mistakes and rectify them by themselves where possible. But if managed at the planning stage through teacher supervision, it can save already tight time of school schedule. The teacher's role, in his opinion, is to move around the class from group-togroup (particularly in classes where students are working in groups, as was the case in this study) and listen to the direction in which student discussion/activity/ experiment is leading them and facilitate only when required.

\section{Comparative analysis of class video for finding change in class talk}

The overall results showed an increase in the share of student talk by 10 percent when compared to 2001 results. Teacher talk in both cases is still more than 50 percent but it was 67 percent in 2001, which reduced to 57 percent in 2003. Consequently, student talk increased from 33 percent in 2001 to 43 percent in 2003. From a constructivist standpoint, this is encouraging, but it is interesting to look at change in each sub-category of teacher talk and student talk to better understand the exact categories contributing to this overall change.

Figure 2 shows a decrease in the percentage of tuning talk and directions in 2003 while connecting and monitoring talk has increased. Decline in tuning talk is not a desired change as the success of constructivist instruction rests on the exploration of previous knowledge, experiences and observations that students bring to the class. A decline in percentage of "Directions" is also seen, which seems to suggest a better management of lesson plan, class time and an increased trust on the students' abilities to manage the procedural work by themselves as compared to classes in 2001 . This decline in percentage of utterances addressing classroom discipline also implies more student involvement in the lesson.

An increase in the connecting talk seems to reflect the better adaptation of the teacher to his role as facilitator or manager. He puts more value in the students' ideas and urges them to learn through understanding the reasons, 
causes and relationships within the phenomenon under study. More connecting talk in turn tends to imply more student involvement in the lesson and increased thinking activity in the lesson.

Monitoring talk has also increased comparatively, which tends to indicate a continuous effort on the part of the teacher to ensure that what is being done is understood in the same manner as intended. This is also an indication of enhanced constructivist compatibility of classroom practices if compared to 2001 .

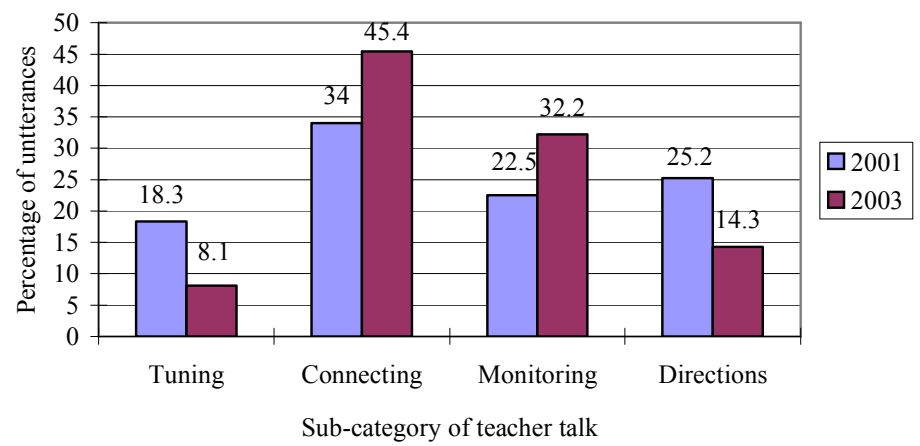

Figure 2. Comparison of percentage of sub-categories of teacher talk 2001 and2003

These results in figure 3 are showing a decline in the percentage of student responses as reported in 2003. But there is an increase in the student self-initiated talk which has more than doubled. This tends to indicate greater willingness on the part of the students to accept involvement in the lesson. The rise in self-initiated talk reflects the customization of students with constructivist learning environment and better understanding of demands of constructivist learning environment which in turn is evidence of increasing opportunities of student talk in classroom.

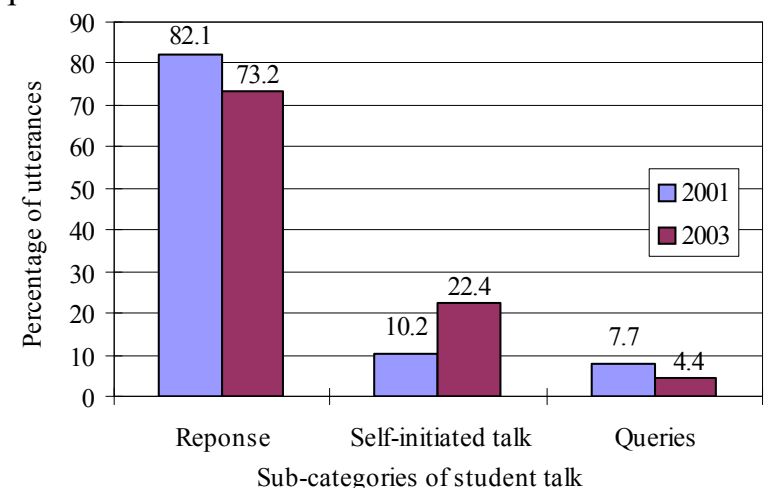

Figure 3. Comparison of percentage of sub-categories of student talk 2001 and 2003 
Students' queries are still an insignificant factor because of their very low percentage rating and the nature of the queries themselves. The low percentage rating may be interpreted as a clear and comprehensive explanation on the part of the teacher, thus leaving a little need for the follow up queries.

\section{DISCUSSION}

There are three interesting aspects of the findings in this study: (a) the sequence of acts causing a change in beliefs i.e. appeal of the theoretical underpinnings for providing an explanation of the phenomenon of learning; (b) class practice can cause change in beliefs but practice may not reflect the extent of change evident in talk about change in beliefs and (c) the possibility of using this sequence of belief change to inform continuous professional development of the teacher.

The sequence of change in beliefs: Theoretical appeal of the constructivist principles of learning worked as a motivating force to help the rethink classroom practice and consequently improve teaching and lead to change in the existing beliefs of the teacher (Bryan \& Atwater, 2002; Levitt, 2002; Waters-Adams, 2006). This once again established that teacher's beliefs are changeable, if change is initiated from inside the teacher. In this case the continuous practice of constructivism revealed its benefits to the teacher and the self-realization of those benefits while teaching in class, motivated him to change his beliefs about scientific knowledge, student participation in lessons, and the teaching and learning of science (Verjovsky \& Waldegg, 2005). In his interview he accepted that he found it useful to talk to students about their learning during the lesson in an attempt to better understand what was going on inside the student's mind. Consequently, he decided to communicate more frequently and give more value to their opinions. Therefore, it can be said that the constructivist explanation of learning provided the context for change but it was ultimately application to classroom practice that caused the actual change in the beliefs of teacher.

It is important to mention here that two lessons which were excluded from the data analysis shown in Figure 2 and Figure 3 (as mentioned in Table 3) to keep the comparability of the data in two years, were very important in terms practice changing beliefs of Fujita and in self-regulation. Students were asked to dissolve a given amount of salt in $50 \mathrm{ml}$. of water and observe the changes (if any) in the resulting solution. During the sharing of observation session, few students reported the appearance of bubbles in the water while stirring the salt and discussion was centered too much on the 
"bubbles" because Fujita's understanding of theoretical principles of constructivist learning retarded him from forcing students to change the focus of discussion. He did not want to dictate but hoped for students discovering that these "bubbles" are not the focus of the lesson. The same chaos continued for the next lesson, ultimately forcing Fujita to re-invent the meaning of "student participation and class discussion" for his teaching. He resolved this impasse by deciding to regulate class discussion and keep students focused on points academically valuable and central to their learning. He learned that aimless freedom and unguided student discussion is not suitable for construction of knowledge and does not help either teaching or learning. Then he restarted the unit again from topic one from lesson 3 with renewed understanding of student participation in the lesson. The Analysis presented here only includes the lesson after this restart.

Talk about practice is not reflecting what is happening in the class and is worth considering: The change in beliefs was found through a selfreporting questionnaire and interview, which clearly showed that the teacher is convinced about the importance and usefulness of exploring students' previous knowledge by providing them with opportunities to speak their mind. However, the analysis of class talk does not correspond to this expressed belief. The proportion of tuning talk in 2003 has actually fallen lower than in 2001, which shows less time devoted to exploring students' previous knowledge. This brings our attention to the factors causing this gap between practice and belief. Fujita has changed but the system of assessing his performance as teacher, the structure of curriculum, the means of assessing student performance; time constraints to finish the list of topics etc, are not flexible enough to provide space to whole heartedly adhere to constructivist principles. For garnishing the full benefits of constructivist learning whole school system and mind-set of the administration also needs to be changed simultaneously (Appleton \& Asoko, 1996).

Implications for professional development of teachers: There is reasonable debate surrounding the mismatch between classroom practices and developments in theory of teaching and learning. This case study indicates that change in teachers' beliefs needs more than a one-shot short training course on theoretical developments in the field of teaching and learning in order to be successfully translated into practice. Nevertheless, studies like this one may provide us with better chances of bringing change in teachers' beliefs and consequently classroom practices, into harmony. 


\section{REFERENCES}

Abd-El-Khalick, F., Bell, R. L., \& Lederman, N.G. (1998). The nature of science and instructional practice: Making the unnatural natural. Science Education, $82,417-436$.

Ambrose, R., Philipp, R., Chauvot, J. \& Clement, L. (2003). A web-based survey to assess prospective elementary school teachers' beliefs about mathematics learning: An alternative to Likert scale. In N. A. Pateman, B. J. Dougherty \& J. T. Zilliox (Eds.), Proceedings of the 2003 joint meeting of PME and PMENA (Vol. 2, pp. 33-39). Honolulu: CRDG, College of Education, University of Hawaii. (available at http://www.sci.sdsu.edu/ CRMSE/IMAP/pubs/Initiating.pdf retrieved on 3-05-07)

Appleton, K. \& Asoko, H. (1996). A case study of a teacher's progress towards using a constructivist view of learning to inform teaching in elementary science. Science Education, 80(2), 165-180.

Brickhouse, N.W. (1990). Teachers' beliefs about the nature of science and their relationship to classroom practice. Journal of Teacher Education, 41(3), 53-62.

Brooks, G. J. \& Brooks, G. M. (1999). In search of understanding: the case for constructivist classrooms. Alexandria: Association for Supervision and Curriculum Development.

Bryan, L. \& Atwater, M. (2002). Teacher beliefs and cultural models: A challenge for science teacher preparation programs. Science Education, 86, 821-839.

Chan, K.W. \& Elliott, R.G. (2000). Exploratory study of epistemological beliefs of Hong Kong teacher education students: Resolving conceptual and empirical issues. Asia-Pacific Journal of Teacher Education, 28, 225-234.

Cooney, T. J., Shealy, B. E. \& Arvold, B. (1998). Conceptualizing belief structures of preservice secondary mathematics teachers. Journal for Research in Mathematics Education, 29, 306-333.

Davis, M.M., Konopak, B.C. \& Readence, J.E. (1993). An investigation of two chapter 1 teachers' beliefs about reading and instructional practices, Reading Research and Instruction. 33, 105-133.

Fang, Z. (1996). A review of research on teacher beliefs and practices. Educational Research, 38, pp. 47-65.

Fulton, K. \& Torney-Purta, J. (2000). How teachers' beliefs about teaching and learning are reflected in their use of technology: Case studies from urban middle schools. Paper presented at the International Conference on Learning with Technology, Temple University, Philadelphia.

Gallagher, J. J. (1991). Prospective and practicing secondary school science teachers' knowledge and beliefs about the philosophy of science. Science Education, 75(1), 121-133.

Hashweh, Z. M. (1996). Effects of science teachers' epistemological beliefs in teaching, Journal of Research in Science Teaching, 33(1), 47-63.

Kagan, D.M. (1992). Implication of research on teacher belief. Educational Psychologist, 27(1), 65-90. 
Lederman, N.G. (1999). Teachers understanding of nature of science and classroom practice: Factors that facilitate or impede the relationship. Journal of Research in Science Teaching, 36, 916-929.

Lederman, N.G., Gess-Newsome, J.G., \& Latz, M.S. (1994). The nature and development of preservice science teachers' conceptions of subject matter and pedagogy. Journal of Research in Science Teaching, 31, 129-146.

Levitt, K. E. (2002). An analysis of elementary teachers' beliefs regarding the teaching and learning in science, Science Education, 86(1), 1-22

Levin, T. \& Wadmany, R. (2005). Changes in educational beliefs and classroom practices of teachers and students in rich technology-based classrooms. Technology, Pedagogy and Education, 14(3), 281-307.

Munby, H. (1982). The place of teachers' belief in research on teacher thinking and decision making, and an alternative methodology, Instructional science, 11(3), 201-225.

Nasir, M., Kono, Y, \& Fujita, R (2002). Constructivism in elementary school science education: a reflective view from inside the classroom, Journal of Educational Research, Tokyo Gakugei University, 6, pp. 1-12.

Newton, P. D. (2002). Talking sense in science: helping children understand through talk, New York: Routledge Flamer.

Pajares F.M. (1992). Teacher's belief and educational research: cleaning up a messy construct. Review of Educational Research, 62(3), 307-322.

Prawat, R. (1990). Changing schools by changing teachers' beliefs about teaching and learning. Elementary Subjects Center Series, No. 19. Lansing: Michigan State University, Center for the Learning and Teaching of Elementary Subjects Institute for Research on Teaching.

Prawat, R. S. (1992). Teacher's beliefs about teaching and learning: a constructivist perspective. American Journal of Education, 100(3), 354-395.

Pintrich, P. R. (1990). Implication of psychological research on student learning and college teaching for teacher education. In W. R. Houston (ed.), Handbook of research on teacher education, New York: McMillan pp. 826-857.

Richardson, V. (1996). The role of attitudes and beliefs in learning to teach. In J. Sikula (ed.), Handbook of research on teacher education. New York: McMillan pp. 102-119.

Tsai, C. (2002). Nested epistemologies: science teacher's belief of teaching, learning and science. International Journal of Science Education, 24(8), 771-783.

Verjovsky, J. \& Waldegg, G. (2005). Analyzing beliefs and practices of Mexican high school biology teacher. Journal of Research in Science Teaching, 42, 465491.

Waters-Adams, S. (2006). The relationship between understanding of the nature of science and practice: The influence of teachers' beliefs about education, teaching and learning. International Journal of Science Education, 28, 919944. 
